\title{
Bentuk Penerapan Eko-Efisiensi pada Rantai Nilai di Klaster Batik Laweyan, Kota Surakarta
}

\author{
Nurrizki Dwianto Widodo \\ PT Bank Mandiri \\ Semarang, Indonesia
}

\begin{abstract}
Eco-efficiency is suitable to be applied on batik production cluster, because it can synergize economic and environmental aspects. Application of eco-efficiency will lead to competitiveness, environmental sustainability, and quality of life better. Batik Laweyan cluster is a cluster that not only has great potential in regional economic development but also potentially pollute the environment. Application of eco-efficiency in an industrial cluster can be seen from the value chain that occurs. Eco-efficiency also cannot be applied without the aid of relevant stakeholders and cluster activities such as collective efficiency.
\end{abstract}

Keywords: Eco-efficiency, Batik Laweyan Cluster, Value Chain

\section{Latar Belakang}

Jenis industri yang paling mendominasi dan berperan besar dalam menyerap tenaga kerja adalah usaha kecil dan menengah (UKM) yang sangat potensial untuk dikembangkan karena dapat bertahan dari krisis moneter yang melanda pada tahun 1997-1998. Salah satu kunci dalam penerapan pengembangan ekonomi lokal adalah melalui pembentukan klaster industri. Terdapat beberapa keuntungan dalam pengembangan klaster yaitu memudahkan UKM masalah pengadaan bahan baku dan mesin, promosi penjualan produk, mengurangi risiko fluktuasi permintaan, mempercepat tukar menukar informasi tentang desain baru, metode pengolahan, dan pengembangan produk baru serta berbagi dalam penelitian dan pengembangan.

Klaster industri memang dirasakan memiliki kontribusi besar dalam penurunan kualitas lingkungan sekitarnya. Kementrian Lingkungan Hidup menyatakan bahwa industri batik merupakan faktor terbesar yang mengakibatkan pencemaran air di Indonesia. Minimnya pengetahuan dan kesadaran dari para pelaku usaha menjadi penyebab terjadinya pencemaran dan ketidakefisienan pada UKM.

Konteks perencanaan wilayah dan kota memiliki tujuan untuk membawa suatu kawasan menjadi lebih baik. Konsep eko-efisiensi sangat penting sebagai pemacu pertumbuhan ekonomi klaster dan menjaga keberlanjutan lingkungan sehingga akan meningkatkan kualitas hidup pelaku usaha serta masyarakat sekitarnya. Eko-efisiensi menawarkan penghematan bahan baku, air, dan energi untuk memangkas adanya barang yang terbuang serta sebagai bentuk menghargai lingkungan karena dapat mencegah adanya limbah yang lebih besar.

\footnotetext{
${ }^{1}$ Korespondensi Penulis: PT Bank Mandiri, Semarang

Email: nurrizkidwiantowidodo@yahoo.com
} 
Selain itu pengelolaan keluaran bukan produk juga dapat memacu tercapainya konsep eko-efisiensi. Pengolahan kembali keluaran bukan produk dapat menjadikan klaster lebih hemat bahkan apabila mampu mengolah keluaran bukan produk menjadi barang ekonomis maka dapat mendatangkan keuntungan tersendiri. Kendala dari penerapan ekoefisiensi pada UKM adalah para pengusaha level kecil dan menengah tidak memilki cukup uang maupun waktu. Namun hal ini tidak benar adanya karena dengan menerapkan ekoefisiensi maka UKM akan memperoleh keuntungan yang lebih besar (WBCSD, 2007: 36) sehingga yang dapat dilakukan adalah memberikan pengertian, pelatihan, dan akses untuk mendapatkan informasi lebih mengenai eko-efisiensi bagi UKM.

Klaster Batik Laweyan atau yang lebih dikenal sebagai Kampoeng Batik Laweyan merupakan kawasan peninggalan Kerajaan Pajang sehingga teknik membatik yang mendominasi pada klaster ini adalah teknik membatik tradisional. Industri batik sangat dekat dengan pencemaran lingkungan karena selain menghasilkan batik, proses produksi batik juga mengeluarkan limbah padat dan cair. Selain itu potensi ketidakefisienan juga dapat terjadi jika tidak dibarengi dengan inovasi untuk pemanfaatan KBP yang masih dapat untuk dijadikan barang ekonomis dan penghematan penggunaan bahan baku, air, dan energi. Menurut laporan dari BLH Kota Surakarta pada tahun 2006, Klaster Batik Laweyan menghasilkan limbah cair pewana sejumlah 110-150 m3 per hari dari 20 pelaku usaha.

KLH, GTZ ProLH, dan Bappedal Jawa Tengah memberikan pengetahuan dan pelatihan mengenai penerapan eko-efisiensi pada UKM di Laweyan untuk menjaga keberlanjutan lingkungan. Pelatihan tersebut dilakukan pada tahun 2006 yang ditindaklanjuti dengan pendampingan dan pembuatan IPAL baik secara komunal maupun individu. Hal tersebut dilakukan agar pelaku usaha dapat melakukan proses produksi secara efisien sehingga akan terjadi penghematan yang membawa pada keuntungan ekonomi dan dapat mereduksi buangan limbah industri ke lingkungan. Konsep eko-efisiensi sendiri juga sangat berperan dalam pengembangan klaster dari sisi ekonomi melalui penghematan bahan baku, air, dan energi. Pemanfaatan keluaran bukan juga dapat digolongkan sebagai penciptaan produk baru sebagai bentuk inovasi pelaku usaha yang akan mendorong perkembangan kondisi perekonomian di Klaster Batik Laweyan.

\section{Rumusan Masalah}

Klaster industri batik tentunya berpotensi memunculkan limbah atau keluaran bukan produk yang lebih besar dibandingkan klaster lainnya. Oleh sebab itu diperlukan penerapan konsep eko-efisiensi yang sangat tepat dalam mewujudkan klaster industri dengan perkembangan ekonomi yang baik dan tetap menjaga keberlanjutan lingkungan. Penerapan eko-efisiensi akan membawa pada efisiensi dalam penggunaan bahan baku, air, dan energi sehingga akan mengurangi buangan limbah ke lingkungan. Selain itu efisiensi juga dapat dilakukan dengan memanfaatkan kembali keluaran bukan produk yang dihasilkan.

Penerapan eko-efisiensi juga tidak terlepas dari peran pemerintah sebagai pembuat kebijakan serta kerjasama dengan pihak ketiga untuk melakukan penelitian dan pengembangan inovasi. Ketidakefisienan dari suatu usaha biasanya muncul dari aktivitas proses produksi karena pada tahap ini energi, air, dan material digunakan untuk membuat produk. Oleh sebab itu dirasa penting bagi Klaster Industri Laweyan untuk dapat menerapkan eko-efisiensi pada aktivitas industri yang berlangsung karena eko-efisiensi mampu mengurangi dampak lingkungan dan memunculkan keuntungan ekonomi dari efisiensi yang dilakukan. Dari uraian yang telah dijelaskan maka muncul pertanyaan penelitian yaitu "bagaimana bentuk penerapan konsep eko-efisiensi pada rantai nilai di Klaster Batik Laweyan?” 


\section{Tujuan dan Sasaran}

Tujuan dari penelitian ini adalah untuk mengidentifikasi bentuk penerapan konsep ekoefisiensi pada rantai nilai di Klaster Batik Laweyan. Untuk mencapai tujuan yang telah disebutkan, dibutuhkan beberapa sasaran yang terkait dengan tujuan penelitian, yaitu:

- Identifikasi perkembangan klaster setelah terbentuk FPKBL dan pelatihan ekoefisiensi di Klaster Batik Laweyan

- Identifikasi karakteristik rantai nilai terkait dengan penerapan eko-efisiensi di Klaster Batik Laweyan

- Identifikasi keluaran bukan produk, tindakan yang kurang efisien, dan perhitungan terhadap indikator eko-efisiensi di Klaser Batik Laweyan

- Identifikasi bentuk penerapan eko-efisiensi pada rantai nilai beserta manfaat dari penerapan eko-efisiensi di Klaster Batik Laweyan

- Identifikasi keterkaitan aktivitas klaster seperti efisiensi kolektif terhadap tindakan eko-efisiensi di Klaster Batik Laweyan

\section{Metode Penelitian}

Penelitian terhadap penerapan eko-efisiensi ini dapat digolongkan dalam menggunakan cara berpikir deduktif. Hal tersebut didasari oleh pengkajian terhadap teori dan literatur pada awal proses penelitian. Teori yang dikaji berguna untuk landasan dalam melakukan penelitian kemudian dari literatur yang dikaji dirumuskan suatu variabel penelitian yang menjadi pedoman dalam identifikasi dan analisis data (Moleong, 2006: 31-37). Pemilihan lokasi studi didasarkan pada adanya klaster industri yang berpotensi untuk terjadi ketidakefisienan seperti klaster industri batik di Laweyan. Setelah melakukan pemilihan lokasi, penelitian dilanjutkan dengan pengumpulan data melalui observasi lapangan, wawancara, dan kajian dokumen. Data yang diperoleh berperan dalam melakukan proses analisis yang diidentifikasi sesuai dengan variabel penelitian yang telah ditetapkan.

Data yang digunakan pada penelitian ini merupakan data primer dan sekunder yang didapatkan melalui wawancara, observasi lapangan, dan kajian terhadap dokumen. Wawancara pada penelitian dimaksudkan untuk mengetahui kondisi klaster serta bentuk penerapan eko-efisiensi secara mendalam terhadap narasumber yang merupakan pengurus klaster, pemerintah, dan pelaku usaha.

Penelitian mengenai bentuk penerapan eko-efisiensi di Klaster Batik Laweyan menggunakan teknik pengambilan sampel berupa non-probability sampling dengan jenis purposive sampling atau pengambilan sampel bertujuan. Justifikasi pemilihan teknik sampling bertujuan karena teknik ini memungkinkan peneliti menemukan narasumber yang menguasai topik penelitian sehingga dapat memberikan informasi secara mendalam dan detail. Pemilihan narasumber yang akan dijadikan responden didasarkan pada kriteria sebaga berikut:

- Pelaku usaha batik yang yang terlibat langsung dalam aktivitas pembuatan batik

- Pihak yang dianggap mengerti sejarah dan perkembangan Klaster Batik Laweyan

- Pihak yang dianggap berwenang dan paham dalam pengelolaan lingkungan dan mengerti sebab dan akibat pencemaran lingkungan serta perkembangan Klaster Batik Laweyan

\section{Teori Eko-Efisiensi pada Klaster Industri}

Beberapa definisi mengenai eko-efisiensi sebenarnya tetap berpegang pada proses untuk meningkatkan pertumbuhan ekonomi dengan efisiensi pada penggunaan sumber daya dan 
energi sehingga mengurangi dampak lingkungan karena mampu mereduksi limbah yang dihasilkan. Sehingga perkembangan ekonomi tetap berjalan tanpa memberikan dampak negatif pada lingkungan. Penerapan eko-efisiensi pada klaster industri dapat meningkatkan performa dari keberlanjutan lingkungan yang berhubungan dengan penciptaan nilai ekonomi atau mereduksi efek negatif pada lingkungan (Schaltegger et al. 2002; Dyllick and Hockerts 2002).

WBCSD (2000: 16) menganjurkan empat tindakan dimana dapat memudahkan pelaku usaha dalam menerapkan eko-efisiensi, yaitu re-engineer processes untuk mereduksi penggunaan sumber daya, polusi, dan mencegah resiko yang akan muncul. Kemudian pelaku usaha juga dapat melakukan revalorize by-products melalui kerjasama dengan pihak lain untuk melakukan zero-waste. Karena terkadang limbah masih dapat diolah kembali menjadi barang bernilai ekonomi bagi pelaku usaha yang lain. Oleh sebab itu dibutuhkan kerjasama untuk meningkatkan efektivitas dari penggunaan sumber daya sehingga pelaku usaha dapat menciptakan barang dengan nilai tinggi dan sumberdaya yang tidak banyak.

Pendesain produk memegang peranan penting dalam suatu usaha karena peran tersebut memiliki efek terhadap biaya dan dampak lingkungan dari suatu produksi, pemeliharanaan produk, dan pembuangan. Sehingga dapat dikatakan bahwa suatu usaha berpeluang melakukan eko-efisiensi melalui re-designing product agar produk yang dihasilkan tidak berdampak besar pada lingkungan dengan lebih sedikit bahan dan mudah didaur ulang. Beberapa pelaku usaha yang inovatif tidak hanya mendesain ulang produknya tetapi juga mencoba untuk menemukan kebutuhan dari pembeli dengan membentuk kembali permintaan serta penawaran akan barang atau re-think market. Biasanya pelaku usaha berpikir bahwa kebutuhan pembeli adalah suatu barang atau material padahal belum tentu seperti itu. Pelaku usaha berpeluang untuk menyediakan pelayanan sebagai ganti atas penjualan produknya sehingga dapat mengurangi intensitas penggunaan material dan energi.

Pengembangan klaster tidak hanya terhenti pada upaya meningkatkan pertumbuhan ekonomi namun juga perlu diimbangi dengan pengetahuan akan pentingnya menjaga lingkungan. Oleh sebab itu diperlukan penerapan konsep yang mampu mengakomodasi pertumbuhan ekonomi berbarengan dengan menjaga lingkungan yaitu eko-efisiensi. Soemarwoto (2004: 118) berpendapat bahwa dengan penerapan eko-efisiensi, dilema antara ekonomi dan keberlanjutan lingkungan adalah semu dan kedua aspek tersebut dapat disinergikan.

WBCSD mengidentifikasi bahwa terdapat tujuh faktor kunci dalam eko-efisiensi, yaitu mengurangi jumlah penggunaan bahan, mengurangi jumlah penggunaan energi, mengurangi pencemaran, meningkatkan kemampuan daur ulang bahan, memaksimalkan penggunaan SDA yang dapat diperbarui, memperpanjang umur pemakaian produk, dan meningkatkan intensitas pelayanan.

Penilaian terhadap eko-efisiensi tidak hanya berhenti pada bentuk penerapan ekoefisiensi yang dilakukan oleh suatu klaster tetapi juga dapat diukur. Pengukuran ekoefisiensi diperoleh dengan membandingkan antara nilai ekonomi atau sosial dengan dampak lingkungan yang mucul. Indikator dari nilai ekonomi dan sosial adalah jumlah barang yang diproduksi atau bisa juga biaya produksi. Sedangkan indikator dari dampak lingkungan yang muncul akibat proses produksi adalah konsumsi energi, konsumsi bahan baku, konsumsi air, emisi gas yang terbuang, dan keluaran bukan produk. Pengukuran ekoefisiensi dilakukan untuk mengetahui performa dan perkembangan, mengidentifikasi potensi efisiensi, dan mengidentifikasi penghematan biaya yang dapat dilakukan untuk meningkatkan penerapan eko-efisiensi. 


\section{Product or Service Value \\ Eco-efficiency $=$ Environmental impact}

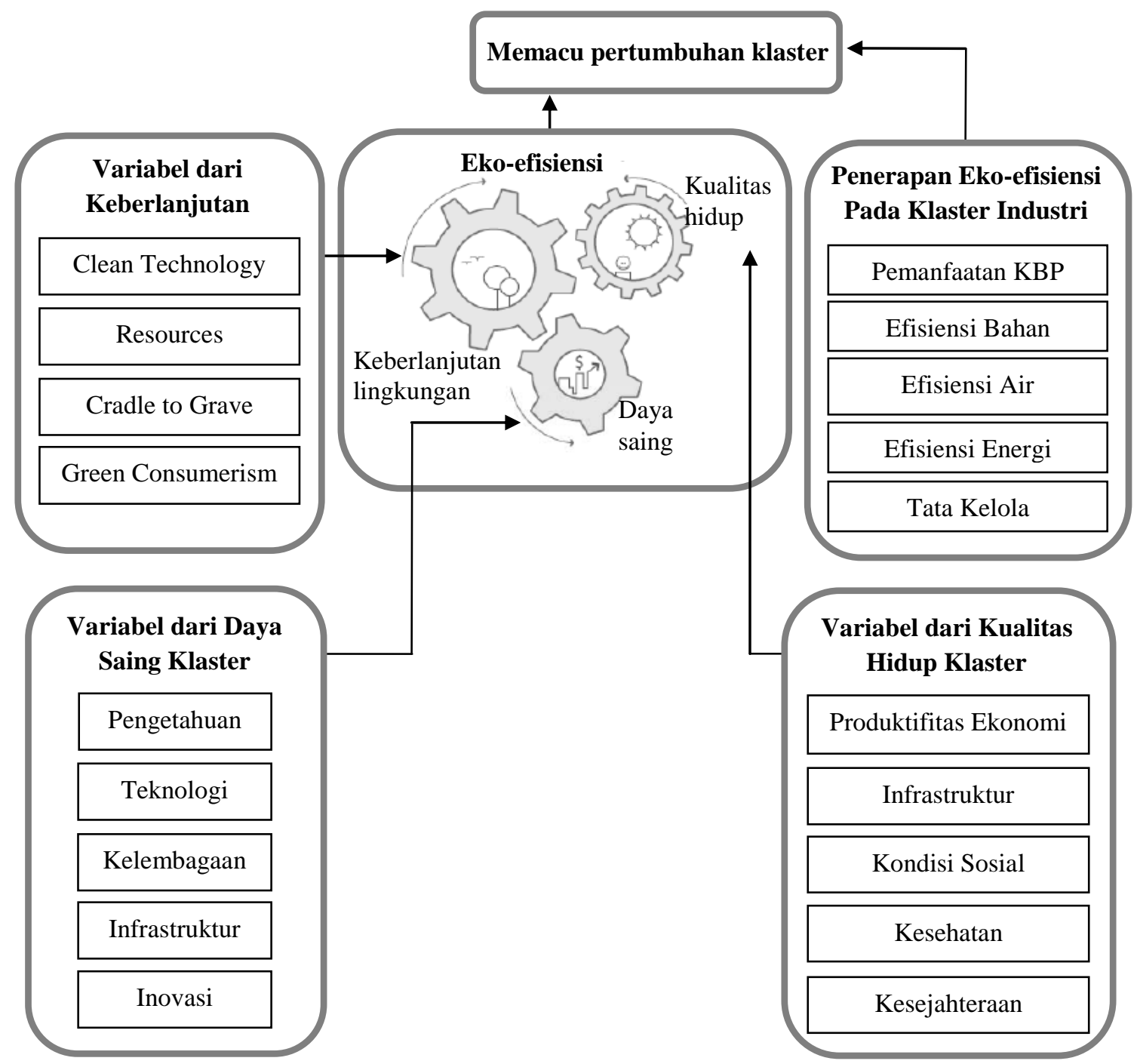

Gambar 1. Keterkaitan Klaster dengan Konsep Eko-efisiensi

\section{Perkembangan Klaster}

Perkembangan Klaster Batik Laweyan cukup bagus dari tahun ke tahun yang ditandai dengan pertumbuhan jumlah pelaku usaha yang sangat pesat terutama sejak dibentuknya FPKBL pada tahun 2004. Klaster batik ini juga telah dikembangkan menjadi daerah tujuan wisata karena kaya akan bangunan bersejarah dengan arsitektur unik serta kekuatan sejarah yang cukup menarik. Hal tersebut mampu menarik wisatawan datang ke Laweyan baik untuk sekedar berjalan maupun membeli produk batik Laweyan dengan motif yang beragam. Pariwisata dapat dijadikan sebagai media promosi produk batik serta dapat mendatangkan nilai tambah tersendiri bagi klaster. 
Permasalahan yang kini dihadapi oleh klaster batik ini adalah terus meningkatnya harga kain mori sehingga daya beli pelaku usaha terhadap kain berkurang. Selain itu perkembangan klaster yang mampu menarik banyak wisatawan juga memunculkan permasalahan baru seperti minimnya lahan parkir karena jalan di laweyan hanya memiliki lebar 2-3 meter. Limbah batik merupakan sorotan utama dari klaster ini karena pertambahan pelaku usaha berarti juga menambah jumlah limbah yang dibuang ke lingkungan sehingga dapat membahayakan lingkungan. Pemerintah setempat bersama GTZ telah memberikan pelatihan mengenai eko-efisiensi bersamaan dengan pembangunan IPAL komunal dan pribadi untuk menjaga lingkungan yang ada serta mengembangkan perekonomian klaster.

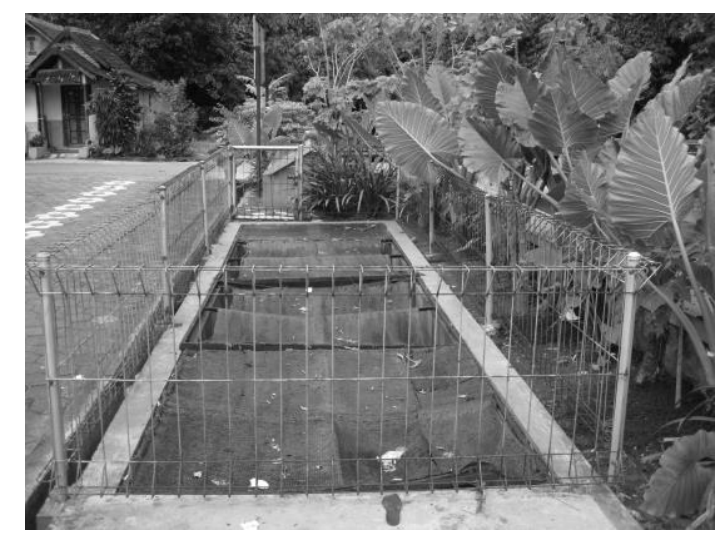

Gambar 2. IPAL Komunal

Bantuan untuk mengembangkan Klaster Batik Laweyan juga terus dilakukan melalui pemberian pelatian dan peralatan. FPKBL dan Pemerintah Surakarta telah melakukan kerjasama dengan Sukoharjo untuk mendukung terwujudnya pariwisata yang bertemakan desa batik. Kabupaten Sukoharjo sendiri telah memberikan wewenang pada Laweyan untuk mengolah lahan kosong di daerah Banaran untuk diolah dan ditanami tanaman bahan pewarna alami.

\section{Rantai Nilai Produksi}

Rantai nilai suatu klaster dapat dilihat dari kondisi input, proses, output produksi, distribusi, dan pemasaran sehingga akan diketahui kondisi inti usaha dari Klaster Batik Laweyan.

\section{Input Produksi}

Baku yang digunakan untuk membuat batik adalah kain mori, bahan pewarna, dan malam. Namun akhir-akhir ini banyak pelaku usaha yang mengeluhkan kenaikan harga kain mori (biasanya katun) yang diakibatkan oleh turunnya jumlah produksi kapas. Untuk bahan pewarna dan malam, pelaku usaha mengaku tidak memiliki permasalahan dalam penyediaannya. Bahan pewarna yang digunakan kebanyakan adalah bahan pewarna kimia seperti indigosol, remasol, dan naptol. Pengguna bahan pewarna alami sendiri masih jarang ditemui meskipun sudah mulai bermunculan dan kebanyakan masih merintis. Peralatan yang digunakan dalam pembuatan batik biasanya masih berupa peralatan tradisional terutama pada batik cap dan tulis karena peralatan yang dipakai sudah berupa turun temurun. 
Faktor yang terpenting dalam pembuatan batik selain malam dan bahan pewarna adalah air karena air berguna untuk proses pencampuran bahan pewarna, proses menghilangkan malam, dan pencucian batik. Pelaku usaha belum melakukan pembelian kolektif dalam penyediaan bahan baku sehingga para penjual kain dapat memainkan harga. Padahal jika melakukan pembelian kain secara kolektif tentunya akan mendapatkan harga yang lebih murah.

\section{Proses Produksi}

Pembuatan batik biasanya dilakukan sendiri oleh pelaku usaha namun terkadang juga dapat dilakukan sistem subkontrak dengan pelaku usaha lain baik yang berada di Laweyan maupun di luar kota seperti Klaten dan Sragen. Pembuatan batik dimulai dengan perendaman kain pada cairan postek untuk memudahkan proses penyantingan yang kemudian dilanjutkan dengan pemotongan kain biasanya menjadi ukuran 200x115 cm sebelum dicanting atau dicap.

Proses penyantingan dan pengecapan dilakukan dengan menempelkan malam yang telah dicairkan pada batik sesuai pola yang diinginkan. Pelaku usaha sudah ada yang beralih dari kompor minyak menjadi kompor gas karena lebih murah. Ceceran malam yang muncul pada proses ini juga mulai dikumpulkan agar dapat digunakan lagi.

Proses selanjutnya adalah pewarnaan yang biasanya menggunakan metode pencelupan dan pencoletan yang biasanya menggunakan pewarna kimia. Pencoletan dirasakan lebih efisien karena tidak ada pewarna yang terbuang dan dapat dicampur kembali jika ada sisa karena pewarnaan dilakukan dengan cara memberikan warna pada kain dengan menggunakan kuas sehingga berbeda dengan teknik pencelupan yang memasukan kain pada air campuran dengan pewarna. Teknik pencelupan menghasilkan limbah cair pewarna yang cukup banyak. Setelah kain mendapatkan warna yang diinginkan kemudian dilanjutkan dengan penguncian warna.

Pelorodan berfungsi untuk melepaskan malam yang menempel pada kain dengan cara perebusan pada baskom besar. Pelaku usaha sudah mulai beralih menggunakan gas sebagai bahan bakar karena lebih cepat dalam memanaskan air. Selain itu ketika menggunakan kayu bakar banyak menimbulkan asap. Malam yang terlepas pada proses ini biasanya dikumpulkan untuk didaur ulang maupun dijual.

Pencucian dilakukan dengan menggunakan bak cuci dengan sistem rolling untuk lebih menghemat air. Pelaku usaha sama sekali tidak ingin mengurangi jumlah penggunaan air karena akan berpengaruh terhadap warna yang didapatkan. Air yang diperoleh biasanya bersumber dari sumur bor.

Proses penjemuran biasanya memakan waktu satu hari tergantung cuaca karena pelaku usaha masih memanfaatkan panas matahari untuk menjemur. Pelaku usaha telah menambahkan atap pada tempat penjemuran sehingga tidak akan basah ketika terjadi hujan dan dapat kering tepat waktu.

Proses terakhir adalah penjahitan dimana kain batik yang sudah jadi dapat dijadikan baju, selendang, dan lain sebagainya untuk memperoleh nilai tambah lebih. Pada proses penjahitan memunculkan sisa kain batik yang jumlahnya cukup banyak. Pelaku usaha sudah mulai memanfaatkan kain perca tersebut untuk dijadikan pernak-pernik agar memiliki nilai jual.

\section{Output Produksi}

Output dari beberapa proses produksi yang telah dilakukan adalah kain batik dan ada yang dijahit menjadi sprei, hem, bed cover, dan lain-lain. Selain batik pewarna kimia, di Laweyan sudah mulai bermunculan pelaku usaha pembuat batik warna alam yang lebih disukai oleh wisatawan mancanegara. Harga jual dari batik warna alam lebih tinggi daripada batik 
dengan pewarna kimia karena memiliki kerumitan lebih dan waktu pembuatannya juga lebih lama dari batik dengan pewarna kimia.

Inovasi produksi juga terus dilakukan seperti memanfaatkan kain sisa untuk dijasikan pernak-pernik seperti tas dan gantungan kunci yang dijual mulai dari Rp. 20.0000. Pemanfaatan kain perca dapat mendatangkan keuntungan melalui penciptaan nilai tambah dari keluaran bukan produk yang dihasilkan serta mengurangi keluaran bukan produk yang dibuang.

\section{Distribusi}

Pemesan pada masing-masing pelaku usaha biasanya merupakan konsumen tetap yang sudah lama baik dari dalam kota maupun luar kota sehingga distribusi barang biasanya dilakukan melalui agen pengiriman barang. Selain itu terdapat beberapa pedagang yang datang untuk mengambil batik di Laweyan sehingga tidak perlu didistribusikan melalui pengiriman barang. Pelaku usaha juga biasanya mendistribusikan produk batik ke Pasar Klewer karena merupakan pasar tua yang ramai akan pengunjung. Lokasi distribusi batik sudah mencapai hingga ke kota-kota besar dan luar negeri, Konsumen mancanegara khusunya Eropa dan Amerika memang lebih menyukai produk batik warna alam karena lebih ramah lingkungan dan tidak panas ketika digunakan.

\section{Pemasaran}

Batik yang sudah jadi dapat langsung dijual kepada konsumen dengan berbagai cara, seperti dijual langsung pada konsumen, diambil oleh para pedagang, dititipkan dari pengusaha batik ke pedagang, dipajang di showroom, dan dibeli oleh perusahaan besar. Upaya eko-efisiensi juga mulai diterapkan oleh pelaku usaha dengan meminimalkan penggunaan energi dengan memperbanyak ventilasi dan menambah ruang terbuka hijau. Namun kebanyakan pemilik showroom masih menggunakan AC dengan alasan untuk membuat pengunjung lebih nyaman.

Pelaku usaha juga mulai menggunakan internet sebagai media promosi. Selain itu pemerintah dan FPKBL telah bekerjasama untuk melakukan pameran batik dan mengadakan event. Upaya peningkatan brand dari masing-masing pelaku usaha juga telah dilakukan dengan mendaftarkan produk batiknya menjadi SNI.

Promosi dari produk juga telah dilakukan melalui pengembangan wisata dimana dapat menarik wisatawan untuk datang berkunjung dan melihat showroom sehingga dapat terjadi transaksi on the spot. Pariwisata yang ada di Laweyan sendiri dapat dimasukan ke dalam tindakan eko-efisiensi karena merupakan tindakan peningkatan intensitas pelayanan serta dapat digolongkan ke dalam ecotourism. Dikatakan demikian karena wisata batik di Laweyan didukung oleh konservasi terhadap peninggalan budaya yang merupakan interpretasi dari perkembangan sejarah khususnya arsitektur bangunan yang dijaga keberlanjutannya. Selain itu sektor wisata juga termasuk ke dalam re-think market yang merupakan tindakan yang membawa pada eko-efisiensi karena klaster industri tidak hanya berpikir untuk menambah jumlah produk secara material namun mulai untuk mengembangkan sektor wisata.

\section{Ketidakefisienan pada Rantai Nilai}

Bentuk dan jenis keluaran bukan produk yang muncul pada klaster ini biasanya berupa limbah cair dan keluaran bukan produk lain seperti asap, abu, sisa malam, dan kain perca. Sisa pewarna yang banyak muncul ketika pelaku usaha menggunakan teknik pewarnaan dengan mencelup dan tidak ingin menggunakan kembali sisa pewarna. Proses pelorodan 
juga menimbulkan sisa malam namun biasanya pelaku usaha sudah melakukan tindakan daur ulang. Limbah cair yang dihasilkan langsung dialirkan ke dalam IPAL. Kain perca yang dihasilkan juga sudah mulai dimanfaatkan untuk membuat hem tambal dan pernakpernik sehingga memiliki nilai jual.

Ketidakefisienan pada input produksi muncul akibat pelaku usaha belum melakukan pembelian secara kolektif yang dapat mengurangi biaya produksi. Pengurangan biaya produksi akan membawa keuntungan bagi pelaku usaha sehingga mendapat uang sisa biaya produksi yang bisa digunakan untuk membeli peralatan penunjang tercapainya ekoefisiensi.

Ketidakefisienan juga muncul akibat pelaku usaha tidak melakukan pencatatan dan pembukuan terhadap bahan yang digunakan dan limbah yang dihasilkan. Kurangnya koordinasi antar pelaku usaha dan buruh batik serta minimnya pengetahuan akan penerapan eko-efisiensi juga dapat menimbulkan ketidakefisienan.

Kendala penerapan eko-efisiensi juga muncul karena IPAL di klaster ini belum mampu mengakomodasi seluruh kebutuhan pelaku usaha. Selain itu efisiensi penggunaan air masih sulit dilakukan karena pelaku usaha beranggapan bahwa jika air dikurangi maka akan mempengaruhi warna yang diperoleh.

Pengukuran terhadap indikator eko-efisiensi sangat diperlukan untuk mengetahui perkembangan penerapan eko-efisiensi sehingga dapat dilakukan perbaikan terhadap proses produksi yang masih dianggap kurang efisien. Perhitungan yang dilakukan dapat dipermudah dengan melihat perbandingan sebelum dan sesudah penerapan eko-efisiensi.

Sebelum melakukan eko-efisiensi dengan teknik pencampuran sisa pewarna dan tidak mencoba untuk mendaur ulang remukan malam total biaya NPO yang didapatkan adalah Rp. 110.872.482,00. Karena tidak mampu memanfaatkan limbah pewarna maka UKM tersebut mengalami kerugian sebesar RP. 13.624.400,00/ tahun. Selain itu karena tidak mampu mendaur ulang remukan malam maka pelaku usaha kehilangan Rp. 7.830.000,00 dan ceceran malam pada saat pengecapan sejumlah Rp. 391.500,00 atau sisa malam sebesar $880 \mathrm{~kg}$.

Penjelasan tersebut membuktikan bahwa dengan menerapkan eko-efisiensi maka pelaku usaha dapat menghindari kerugian secara finansial dan mampu menjaga jumlah buangan limbah ke alam. Komponen yang menjadi pembeda pada proses produksi sebelum dan sesudah menerapkan eko-efisiensi adalah pada pemanfaatan sisa lilin dan pewarna.

Total biaya NPO suatu UKM yang didapatkan setelah melakukan eko-efisiensi yaitu RP. 95.212.482,00. Karena sudah mampu memanfaatkan dan menggunakan kembali sisa pewarna maka tidak terdapat kerugian yang muncul. Selain itu karena sudah mampu memanfaatkan limbah malam sebanyak $22 \%$ maka hanya mendapat kerugian sebesar Rp. 6.107.400,00 dan ceceran lilin sebesar Rp. 78.300,00. Limbah malam yang dihasilkan sesudah menerapkan eko-efisiensi adalah $669,6 \mathrm{~kg}$.

Perhitungan eko-efisiensi yang dilakukan dengan membandingkan jumlah kain yang dihasilkan dengan buangan lilin akibat remukan dan ceceran lilin pada saat pengecapan. Proses produksi sebelum dan sesudah melakukan eko-efisiensi menghasilkan 86.132 meter. Sebelum melakukan efisiensi didapatkan indikator eko-efisiensi sebesar 97,8 meter kain/ kilogram malam sehingga setiap 97,8 meter menghasilkan $1 \mathrm{~kg}$ sisa malam, sedangkan ketika sesudah melakukan eko-efisiensi didapatkan angka eko-efisiensi sebesar 128,6 meter kain/ kilogram malam. Jadi setiap 128,6 meter kain batik yang dihasilkan menimbulkan sisa malam sebanyak satu kilogram. Hal tersebut membuktikan bahwa setelah melakukan eko-efisiensi pelaku usaha dapat melakukan efisiensi sebanyak 30,8 meter untuk setiap kilogram malam sisa yang dihasilkan. Dan secara tidak langsung mendapatkan keuntungan sebesar Rp. 2.035.800,00 karena mampu melakukan daur ulang terhadap sisa malam. 


\section{Penerapan Eko-Efisiensi Pada Rantai Nilai}

Efisiensi terhadap bahan baku dapat dilakukan dengan pengukuran kain untuk mengurangi kain perca yang dihasilkan. Selain itu penggunaan takaran yang tepat dalam pencampuran warna sesuai dengan kebutuhan juga dapat mengurangi jumlah sisa pewarna yang muncul. Pembelian kolektif termasuk dalam tindakan efisiensi karena dapat mengurangi biaya produksi. Tindakan eko-efisiensi juga dapat dilakukan menggunakan bahan baku alami karena ramah lingkungan dan tidak menimbulkan bau menyengat.

Air memegang peranan penting dalam proses pembuatan batik terutama pada proses pelorodan dan pencucian. Efisiensi dalam penggunaan air memang sulit untuk dilakukan karena pelaku usaha beranggapan bahwa dengan menghemat air maka akan berpengaruh terhadap warna yang diperoleh. Namun upaya efisiensi air telah dilakukan dengan menggunakan bak pencucian, mencegah kebocoran air pada selang dan pipa, serta menampung air hujan.

Efisiensi energi telah dilakukan pelaku usaha melalui penggunaan atap transparan untuk mengurangi pemakaian lampu. Substitusi bahan bakar dari kayu dan minyak tanah menjadi gas dapat dimasukan dalam efisiensi energi karena dengan penggunaan gas dapat memperoleh panas yang lebih cepat dan harganya tidak terlalu mahal. Selain itu pengembangan bahan bakar alami seperti bio-etanol juga telah dilakukan oleh klaster ini sehingga dapat lebih ramah lingkungan. Penghematan energi pada showroom batik juga telah dilakukan dengan penambahan open space, ventilasi, dan tanaman untuk mengurangi penggunaan AC.

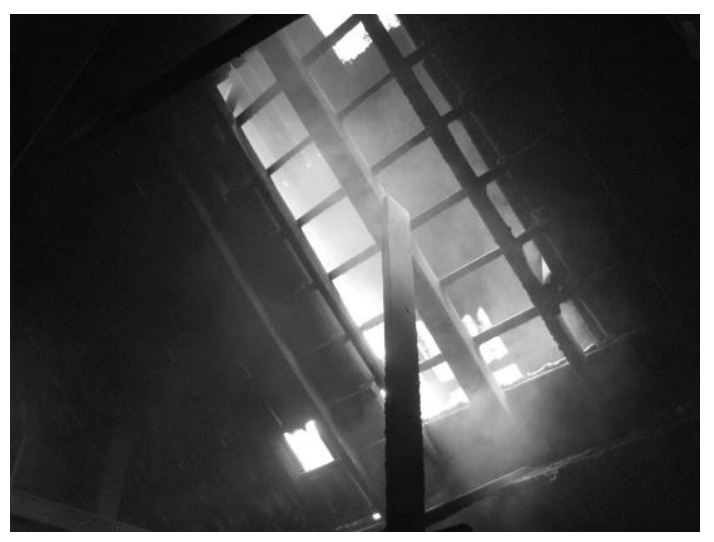

Gambar 3. Penggunaan Atap Transparan

Pengolahan limbah pada Klaster Batik Laweyan telah dilakukan melalui penggunaan teknologi IPAL baik secara komunal maupun individu namun memang belum mampu mengakomodasi seluruh limbah yang dihasilkan oleh pelaku usaha. Upaya pemanfaatan keluaran bukan produk juga telah dilakukan dengan memanfaatkan sisa pewarna untuk dicampur kembali dan digunakan pada proses selanjutnya. Begitu juga dengan sisa malam yang ditangkap dan didaur ulang ataupun dijual ke penadah sehingga malam yang yang sisa tidak dibuang tapi dapat mendatangkan keuntungan baik secara finansial maupun keberlanjutan lingkungan. Inovasi pada pemanfaatan keluaran bukan produk dapat dilakukan dengan memanfaatkan kain perca yang ada untuk dijadikan hem tambal dan pernak-pernik sehingga memiliki nilai jual dan ternyata tanggapan konsumen juga cukup bagus mengenai produk tersebut. 


\section{Keterkaitan Penerapan Eko-Efisiensi dengan Klaster}

Penerapan eko-efisiensi pada klaster dimaksudkan untuk mengembangkan perkonomian dan keberlanjutan lingkungan melalui penghematan sumberdaya dan pemanfaatan limbah sehingga akan meningkakan kualitas hidup. Aktivitas klaster sendiri juga turut membantu tercapainya penerapan eko-efisiensi yang ada seperti efisiensi kolektif yang muncul akibat kedekatan geografis. Hal tersebut terbukti dari sharing teknoligo yang dilakukan seperti penggunaan IPAL komunal yang merupakan efisiensi kolektif pasif. Efisiensi kolektif aktif juga muncul akibat kerjasama antar pelaku usaha untuk membentuk KUB baik warna alami untuk mendorong dan memotivasi pelaku usaha dalam menggunakan bahan pewarna alami. Selain itu kerjasama dalam penjualan perca batik juga dilakukan sehingga ketika ada pelaku usaha yang tidak memiliki waktu untuk memanfaatkan kain percanya maka dapat dijual pada UKM lain.

Hubungan antar stakeholder yang terlibat dalam klaster juga turut menunjang terciptanya eko-efisiensi pada Klaster Batik Laweyan. Adanya FPKBL cukup membantu dalam mengkoordinasikan beberapa stakeholder yang ada untuk mengembangkan klaster. Stakeholder yang ada telah memberikan bantuan baik pelatihan, pendampingan, dan peralatan untuk menunjang terciptanya eko-efisiensi. Stakeholder kunci yang dapat meningkatkan inovasi dan daya saing adalah universitas, pemerintah, dan pelaku usaha atau sering disebut triple helix model. Universitas berperan dalam melakukan penelitian, seperti pengembangan bio-etanol. Pemerintah memberikan pelatihan dan bantuan peralatan serta menjalin kerjasama dengan berbagai pihak. Pelaku usaha sendiri berperan dalam meningkatkan kapasitas produksi dengan menerapkan eko-efisiensi secara konsisten.

\section{Kesimpulan}

Pelaku usaha pada Klaster Batik Laweyan telah mencoba untuk menerapkan konsep ekoefisiensi pada aktivitas rantai nilai. Oleh sebab itu Klaster Batik Laweyan dapat dikatakan sebagai klaster yang sedang menuju pada keberlanjutan lingkungan karena telah mencoba menerapkan konsep eko-efisiensi pada aktivitas industrinya. Penerapan eko-efisiensi pada klaster akan membawa pada keberlanjutan lingkungan, peningkatan daya saing, dan perbaikan kualitas hidup di klaster tersebut (IUTC, 2010).

Upaya penerapan eko-efisiensi di Klaster Batik Laweyan tidak terlepas dari kerjasama dan peran stakeholder terkait. Adanya efisiensi kolektif baik pasif maupun aktif turut membantu dalam pencapaian tindakan eko-efisiensi. Adanya kerja sama aktif dapat meningkatkan intensitas sharing informasi dan saling membutuhkan untuk menuju dalam tindakan eko-efisiensi. Gabungan dari efisiensi kolektif pasif dan aktif dapat memperkuat daya saing dari suatu klaster serta meningkatkan kemampuan dalam berkompetisi secara global (Nadvi, 1999: 1608).

Proses partisipasi dari masing-masing stakeholder sangat dibutuhkan untuk mengimplementasikan konsep eko-efisiensi pada skala klaster dan wilayah yang lebih luas. Stakeholder kunci yang dimaksud adalah pelaku usaha (industri), pemerintah, dan universitas atau yang lebih dikenal dengan triple helix model. Melalui triple helix model dapat meningkatkan daya saing dan produksi melalui pengembangan pengetahuan dan inovasi teknologi (Vargas, 2006: 10). Klaster Batik Laweyan telah melakukan kerjasama yang diwakili oleh FPKBL dan pelaku usaha dengan LSM seperti GTZ, pemerintah, dan pihak universitas. Selain itu klaster ini juga telah bekerjasama dengan pihak Pemerintah Kabupaten Sukoharjo untuk mengolah lahan kosong untuk ditanami bahan pewarna alami. 


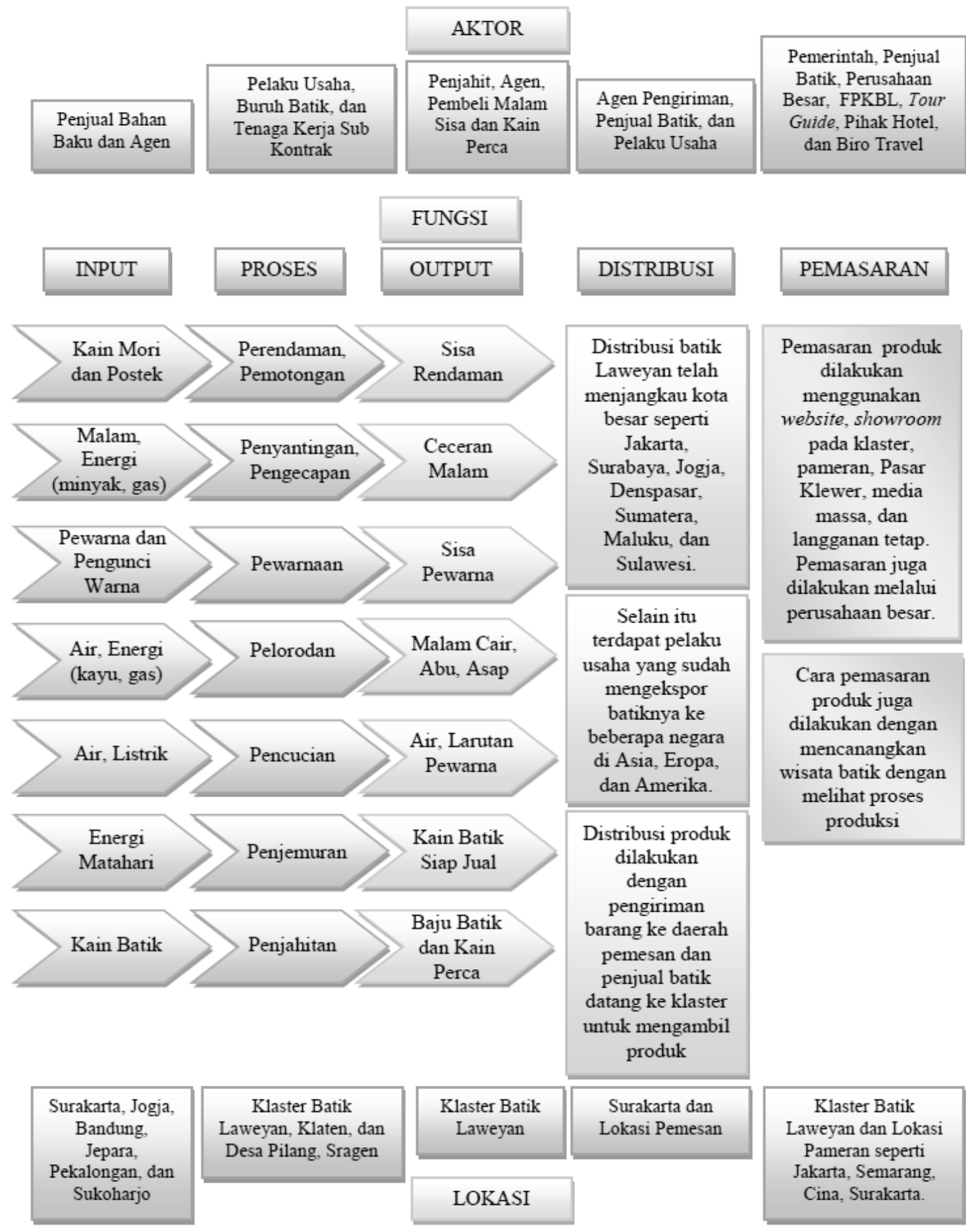

Gambar 4. Rantai Nilai Produksi Pada Produk Inti Klaster Batik Laweyan 


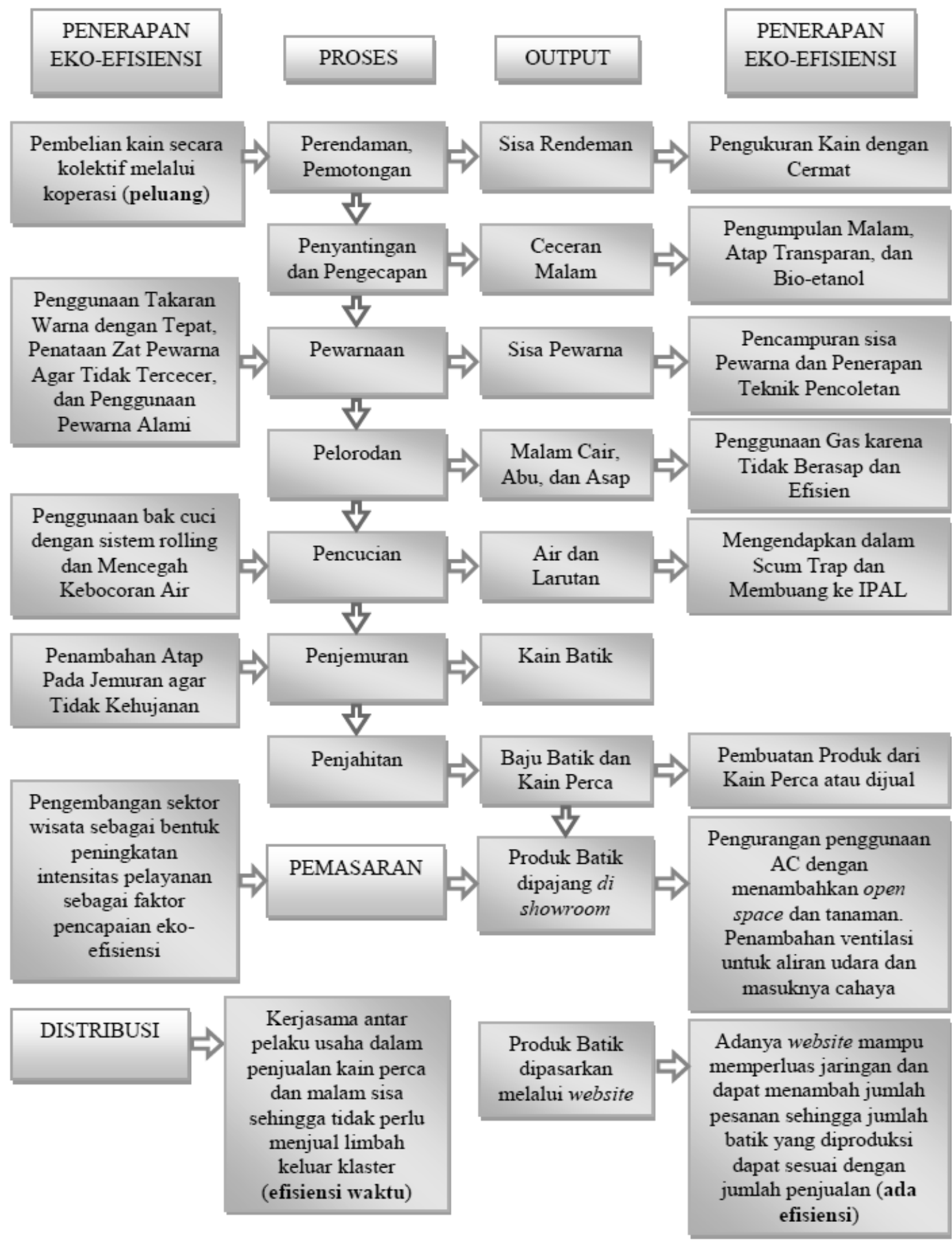

Gambar 5. Penerapan Eko-efisiensi Pada Rantai Nilai 


\section{Bentuk Penerapan Eko-Efisiensi pada Rantai Nilai di Klaster Batik Laweyan, Kota Surakarta}

Klaster Batik Laweyan yang telah menerapkan konsep eko-efisiensi melalui penghematan, pengelolaan keluaran bukan produk, dan tata kelola yang baik, mampu menciptakan kawasan industri yang ramah lingkungan serta memiliki kekuatan ekonomi. Peluang peningkatan intensitas pelayanan dalam upaya penerapan eko-efisiensi juga telah dilakukan melalui pengembangan Laweyan sebagai daerah tujuan wisata batik. Pengembangan wisata dapat menjadi media promosi dan pemasaran produk batik yang cukup efektif karena akan menarik konsumen datang ke Laweyan. Sektor pariwisata di Laweyan juga dapat dikembangkan menjadi ecotourism karena berdasar pada kekayaan kultur dan budaya baik secara arsitektur maupun proses pembuatan batik itu sendiri.

\section{Rekomendasi}

Rekomendasi yang diberikan tentunya berkaitan dengan penguatan dan peningkatan penerapan eko-efisiensi pada Klaster Batik Laweyan. Hal tersebut dimaksudkan untuk mengembangkan klaster secara berkelanjutan baik secara ekonomi dan lingkungan.

Pemerintah perlu untuk melakukan kerjasama dengan berbagai pihak yang berkompeten dalam upaya pengembangan teknologi dan inovasi. Adanya inovasi dan teknologi akan menunjang terciptanya praktek eko-efisiensi yang lebih baik dari sebelumnya. Selain itu diperlukan juga pembentukan koperasi untuk melakukan pembelian secara kolektif sehingga mampu mengurangi biaya produksi.

Pelaku usaha sendiri perlu untuk menjaga konsistensi dalam terus menerapkan ekoefisiensi serta terus berusaha untuk mengembangkan inovasi terkait dengan eko-efisiensi khususnya pada rantai nilai produksi batik di Laweyan. Selain itu juga dibutuhkan upaya bersama dalam menjaga situs bersejarah untuk pengembangan pariwisata untuk meningkatkan instensitas pelayanan dan sebagai media promosi batik.

\section{Daftar Pustaka}

Anderson, Thomas, et.al. 2004. The Cluster Policies Whitebook. Malmo: IKED

Berkel, Rene Van. 2007. "Cleaner Production And Eco-efficiency Initiatives In Western Australia 1996-2004”. Journal of Cleaner Production, Volume 15: 741-755.

Bina Wijaya, Holi. 2006. Pengembangan Klaster Usaha Di Propinsi Jawa Tengah. Laporan Kegiatan Internship di FPESD Jawa Tengah Dalam rangka Hibah Kompetisi A2 Jurusan Perencanaan Wilayah dan Kota Fakultas Teknik Universitas Diponegoro

Blakely, Edward J. 1994. Planning Local Economic Development : Theory and Practice. London : Sage Publication.

Caneghem, J. Van et al. 2010. "Eco-efficiency Trends Of The Flemish Industry: Decoupling Of Environmental Impact From Economic Growth”. Journal of Cleaner Production, Volume 18: 1349-1357.

Castillejo, Juan A. Manez, dkk. On The Role of Process Innovations on SMEs Productivity. Universitat de Valencia and ERI-CES.

Cogoy, Mario. 2009. “A Model of Eco-Efficiency and Recycling”. Economics, Volume 3: 1-30.

D’Agosto, Marcio dan Suazana Kahn Ribeiro. 2004. “Eco-efficiency Management Program (EEMP) - A Model For Road Fleet Operation”. Transportation Research, Volume 9: 497-511.

Eco-efficiency: Creating More Value with Less Impact. 2000. World Business Council for Sustainable Development. North Yorkshire: World Business Council for Sustainable Development.

Eco-efficiency Learning Module. 2005. World Business Council for Sustainable Development.

Lafferty, William M (ed.). 2004. Governance for Sustainable Development: The Challenge of Adapting Form to Function. Massachusetts: Edward Elgar Publishing Inc. 
Lema, Rasmus dan Bjarke Hesbjerg. 2003. The Virtual Extension: A Search For Collective Efficiency in The Software Cluster Bangalore. Roskilde: Roskilde University.

Measuring Eco-efficiency: A Guide to Reporting Company Performance. 2000b. World Business Council for Sustainable Development.

Mickwitz, Per et al. 2006. "Regional Eco-efficiency Indicators E A Participatory Approach”. Journal of Cleaner Production, Volume 14: 1603-1611.

Miron, Dumitru. 2008. "Linking The Double Helix of Learning and Work To The Triple Helix of University Industry - Government in The Europe of Knowledge “. Management and Marketing, Volume 3 (4): 3-20.

Nadvi, Khalid. 1999. "Collective Efficiency and Collective Failure: The Response of The Sialkot Surgical Instrument Cluster to Global Quality Pressures”. World Development, Volume 27 (9): 1605-1626.

Kementrian Negara Lingkungan Hidup. 2007. Panduan Penerapan Eko-efisiensi. Jakarta : Kementrian Negara Lingkungan Hidup.

Schmitz, Hubert dan Khalid Nadvi. 1999. "Clustering and Industrialization: Introdusction”. World Development, Volume 27 (9): 1503-1514.

Setiadi, Rukuh. 2007. "Promosi Eko-efisiensi dan Produksi Bersih bagi Usaha Kecil Menegah di Jawa Tengah". Jurnal Tata Loka, Volume 9: 35-52.

Soemarwoto, Otto. 2004. Atur Diri Sendiri: Paradigma Baru Pengelolaan Lingkungan Hidup. Yogyakarta: Gadjah Mada University Press. 
302 Bentuk Penerapan Eko-Efisiensi pada Rantai Nilai di Klaster Batik Laweyan, Kota Surakarta

JURNAL WILAYAH DAN LINGKUNGAN, 1 (3), 287-302 